\title{
Recent shifts in shade tolerance and disturbance traits in forests of the eastern United States
}

\author{
Brice B. Hanberry D
}

\begin{abstract}
Background: Current forests of the eastern USA have the potential to succeed in composition to more shade-tolerant species. However, long-term processes of transition from fire-tolerant tree species to fire-sensitive species and effects of current land use on forests may interfere with successional progression.

Methods: I examined if forests in three regions have increased in shade tolerance and if life history strategy groups that represent response to disturbance (i.e., fire-tolerance, early-successional species based on low shade tolerance, mid-successional species, late-successional species, and trees valued for traits related to short harvest rotations) have changed, using Forest Inventory and Analysis surveys, adjusted for comparison, and generalized linear mixed models to assess approximately 30 year trends, with adjustments to equalize different survey methods.

Results: Although statistically significant, a slight increase of 2 to $4 \%$ in regional mean shade tolerance may not be ecologically significant. In the central East, mid-successional species replaced early-successional species and early-successional species replaced fire-tolerant oaks, resulting in an overall shift from fire-tolerant oaks to mid-successional species. Decreased fire-tolerant pine species and increased planted pine species were the major changes in the northern Southeast and Coastal Plain.

Conclusions: The successional process of increased composition by shade-tolerant species over time was overshadowed by land use changes that resulted in decreased fire-tolerant species and increased planted pine. Furthermore, frequent land use disturbance may continue to prevent the slow progress of compositional succession to very shade-tolerant species.
\end{abstract}

Keywords: Disturbance, Eastern United States, Fire, Land use, Mesophication, Oak, Pine, Succession, Traits

\section{Introduction}

Succession in composition to more shade-tolerant species was rare in forests of the eastern USA before EuroAmerican settlement (1600s to 1800 s; e.g., Hanberry et al. 2018a). Excluding boreal forests, infrequent severe disturbance, generally by wind and fire, occurred on rotations of hundreds of years that were longer than tree lifespans; when stand-replacing disturbance occurred, canopy loss was diffuse (Seymour et al. 2002). Other disturbances, such as frequent surface fires of less than 35 years that removed small trees, tended to produce

Correspondence: brice.hanberry@usda.gov

Rocky Mountain Research Station, USDA Forest Service, Rapid City, SD 57702, USA

Springer Open

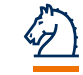

mortality in a few overstory trees, resulting in gaps that allowed recruitment of tree regeneration, albeit with some amount of intermediate severity disturbance (Hart and Kleinman 2018). Historical forests auto-replaced, i.e., species that were present before disturbance provided the species pool for tree replacement, resulting in compositional inertia. Historical forests were landscapes of fire-tolerant oak- or pine-dominated ecosystems (i.e., $>50 \%$ oak, $>70 \%$ oak-shortleaf pine [Pinus echinata $],>80 \%$ longleaf pine $[P$. palustris]; Nowacki and Abrams 2008; Hanberry et al. 2018b; Hanberry et al. 2019), and areas of extremely shade-tolerant species such as American beech (Fagus grandifolia) for thousands of years in the eastern USA (Prentice et al. 1991;

(c) The Author(s). 2019 Open Access This article is distributed under the terms of the Creative Commons Attribution 4.0 International License (http://creativecommons.org/licenses/by/4.0/), which permits unrestricted use, distribution, and reproduction in any medium, provided you give appropriate credit to the original author(s) and the source, provide a link to the Creative Commons license, and indicate if changes were made. 
Grimm and Jacobson 1992; Williams et al., 2004; Hanberry 2019). Both late-successional species and firetolerant species were potential dominant species in forests with infrequent stand-replacing disturbance, depending on whether surface fires occurred (Hanberry 2019).

Due to extensive harvest of eastern forests and exclusion of fire by 1920 to 1930 that historically maintained widespread fire-tolerant oak and pine forests, eastern forests have the potential to progress in composition to very shade-tolerant species, according to successional and stand dynamics concepts (Frost 1993; Egerton 2015). Forests generally are 40 to 80 years old in the northern part of the eastern USA and $<60$ years in the southern part (Pan et al. 2011). Many species now can establish and increase in current forests, unlike species in historical forest ecosystems that were filtered by low severity disturbance or remained extremely shade-tolerant under limited disturbance. Typical dense eastern forests currently contain a legacy of fire-tolerant oak and pine species and latesuccessional species from historical forests and a variety of early- to mid-successional species, such as red maple (Acer rubrum) and eastern redcedar (Juniperus virginiana), which historically were restricted to firebreaks of wetlands or rocky outcrops (Hanberry et al. 2014; Hanberry et al. 2018b; Hanberry 2019).

While surface fires may have been the major historical land use and tool of indigenous peoples to clear forest understories (Bowman et al. 2013), current land use involves frequent removal of overstory trees, which regulates tree establishment and composition (Pan et al. 2011). For example, in the southeastern USA after fire exclusion, fire-sensitive broadleaf species increased while pine-dominated forests decreased until pine plantations become progressively common after about 1950, reversing conversion to fire-sensitive broadleaf and/or mixed forests (Frost 1993; Conner and Hartsell 2002). The southeastern USA has been planted widely with loblolly and slash pines (Pinus taeda and Pinus echinata) that are on short rotations of a few decades before harvest (Hanberry et al. 2018b). These pine species are not fire-tolerant and historically were relegated to protected areas, such as wetlands (e.g., loblolly is a wet soil and slashes are swamps). Even in relatively undisturbed forests of the northeastern USA, harvesting causes more than half of all mortality (on a volume basis; Brown et al. 2018). Thus, although succession to very shadetolerant tree species is one potential trend in eastern forests, it may be unlikely that there is compositional progression in shade tolerance due to frequent overstory disturbance of less than 100 years (Pan et al. 2011).

One of the most enduring models of primary plant strategies depends on trade-offs in resource allocation to maximize fitness under different productivity and disturbance scenarios (Grime 1977). In general terms, stress tolerators succeed in conditions that limit productivity, ruderals succeed in conditions that destroy plant biomass, and competitors succeed in conditions that do not limit productivity or destroy plant biomass. These three strategies can be adapted to large scales if a regional disturbance such as frequent surface fire is the stress that limits tree production and outcomes are based on type and attributes of disturbance (Fig. 1). Stress tolerators of oak and pine are dominant under frequent, low-severity surface fire that limits productivity. The primary life history strategy of historically dominant oak and pine species was fire tolerance, which allowed dominance under low or occasional mixed severity fire regimes (Arthur et al. 2012). Firetolerant tree species have evolved a number of functional traits, including thick bark on mature trees, the ability to resprout after topkilling, allocation of resources to root rather shoot development, and protection of buds, to survive under the filter of frequent surface fire. Late-successional species of high shade tolerance are dominant under infrequent stand-replacing disturbance (i.e., shade tolerators), while early- to midsuccessional species of low to moderate shade tolerance are dominant under relatively frequent stand-replacing disturbance (i.e., overstory disturbance tolerators).

Because forests of the eastern USA are expressing loss of fire-tolerant oak and pine species due to fire exclusion and land use effects from increased overstory tree removal and planting of pines, the successional process to more shade-tolerant species may be disrupted. My objective was to determine mean shade tolerance and life history strategy groups that represent traits in response to disturbance for three major regions of the eastern USA: the Coastal Plain and north Southeast of the southeastern USA and central East (Fig. 2; Ecomap 2007). I used tree strategy groups of fire-tolerant oaks and fire-tolerant pines (i.e., frequent understory disturbance of less than 35 years and infrequent overstory disturbance of hundreds of years); the gradient of early-, mid-, and late-successional species based on shade tolerance values (characterizing a gradient of overstory disturbance from frequent to infrequent) and planted pines, which reflect functional traits that translate into valuable wood products, such as wood density and rapid growth, under extremely frequent stand removal (i.e., 20 to 30 years; Fig. 1). A wide ecological separation exists between planted pines and fire-tolerant pines because planted pines are fire-sensitive, with limited historical distribution and abundance due to confinement to wetlands, which act as firebreaks, whereas historically abundant fire-tolerant pines typically are not grown as 
Tree strategies under landscape disturbance or land use

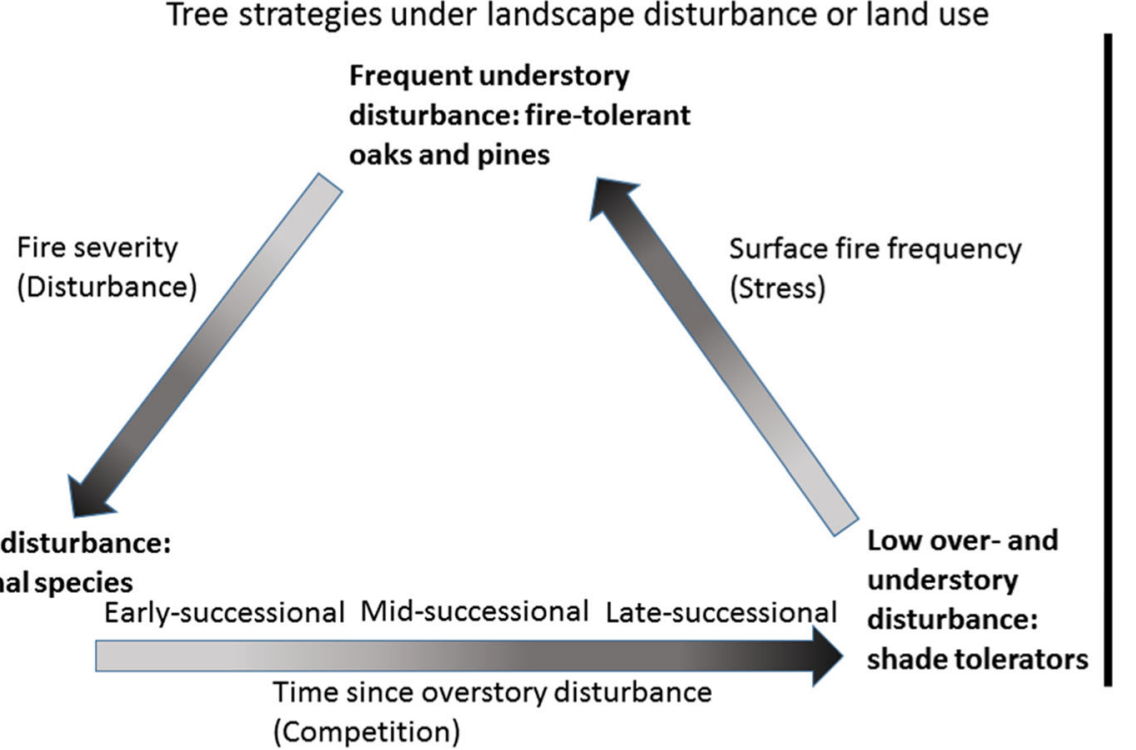

Land use of plantations: planted pines supersede other tree strategies

Overstory disturbance: successional species

(n)

Fig. 1 Plant strategies modified for processes at a landscape scale. Planted pines replace trees of any plant strategies

plantation species due to slow initial aboveground growth while investing resources in belowground growth, which is protected from fire.

\section{Methods}

I used the oldest and most recent US Department of Agriculture Forest Service Forest Inventory and Analysis (FIA) surveys, with adjustments for survey changes over time (Hanberry and Hansen 2015). Large-scale, long-term comparisons in US forests would not be possible without use of FIA surveys, which can be improved by use of adjustments to make more accurate estimates. The USDA Forest Service Forest Inventory and Analysis (FIA DataMart, http://www.fia.fs.fed.us/tools-data) collects information from nationwide plots (Bechtold and Patterson 2005). Plot designs, sampling intensity, and inventory cycles became standardized after about 1999, and 20\% of plots are measured each year with plots located at a standard intensity of one plot every 2400 ha. Each standard FIA plot contains a central subplot surrounded by three outer subplots; the subplots are 7.3 $\mathrm{m}$ in radius, in which all trees $\geq 12.7 \mathrm{~cm}$ in diameter are measured. Trees $<12.7 \mathrm{~cm}$ in diameter are sampled in smaller areas within subplots, which I excluded due to inconsistencies between old and new measurement procedures, and generally, most small trees will not survive.

Hanberry and Hansen (2015) developed a weighting factor to account for differences caused by various sampling intensities between states and calculated density by species, following procedures described in Bechtold and Patterson (2005), by ecological subsection, which are the smallest ecological unit of a land classification system provided in FIA surveys (Ecomap 2007; Fig. 2). This procedure is best for equalizing comparisons, whereas current values of tree metrics should be derived directly from unadjusted surveys. I selected the oldest available surveys, which had measurement dates ranging from 1966 to 2001 (mean survey date = 1973 for the Coastal Plain, 1974 for the north Southeast, 1985 for the central East), and the most recently completed cycles, which had measurement dates ranging from 2000 to 2013 (mean survey date $=2009$ for all regions). There were about 14,000 plots in the Coastal Plain, 13,000 plots in the north Southeast, and 25,000 plots in the central East.

To document compositional changes, I calculated species composition, or percent that each species represents of the total number of all trees, for the central eastern USA, northern southeastern USA, and Coastal Plain of the southeastern USA (Fig. 2). This is a measure of number of each species relative to other species, without a weighting due to different diameters that typically dampens magnitude of change. I then divided species into tree strategy groups of early-successional, midsuccessional, and late-successional, fire-tolerant oaks and pines and planted loblolly and slash pines that allocate resources to traits valuable for rapid wood product generation (see Table 1 for scientific names and groups of any species currently $\geq 1.5 \%$ of all trees; Fig. 1). For the continuous successional gradient, I used shade tolerance measured on a continuous scale of increasing tolerance from $<1$ to 5 , developed by Niinemets and 


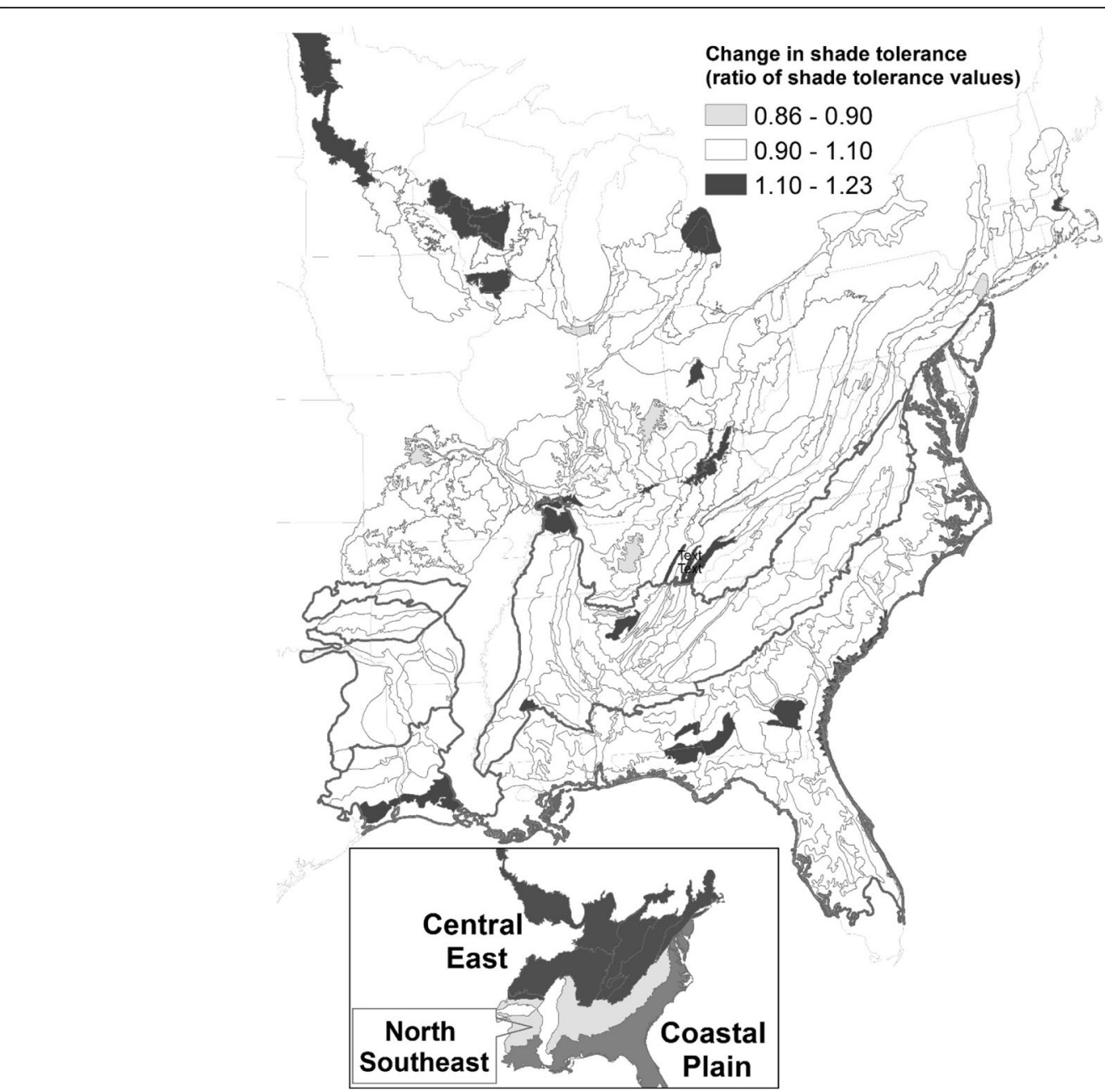

Fig. 2 Change in shade tolerance (ratio of shade tolerance values) between older and more recent FIA surveys by ecological subsection (light outlines). The three regions are displayed in the inset panel

Valladares (2006) to group early-successional species with shade tolerance $<2.5$, mid-successional species with shade tolerance $\geq 2.5$ and $<3.75$, and late-successional species with shade tolerance $\geq 3.75$. I subdivided the fire-tolerant group into fire-tolerant oaks (white oak, black oak, post oak, chestnut oak, blackjack oak, bur oak, northern red oak, scarlet oak, and southern red oak) and fire-tolerant shortleaf and longleaf pines to clarify whether pines or oaks are changing in each region. Although there was no way to track transitions in strategy groups by forest plots, an approximation may be made by assigning the majority group to each ecological subsection and time interval and then comparing transitions in major group.

I also determined mean shade tolerance, using shade tolerance values by species. To test statistical significance of changing shade tolerance over time, or repeated measures, I used generalized linear mixed models (SAS Proc Glimmix; SAS software, version 9.4, Cary, NC,
USA) to compare mean shade tolerance values by ecological subsection between oldest and newest FIA surveys for each region. Based on residuals, I selected the normal distribution with the log link. To specify that values by ecological subsection were repeated, I added residual to a random statement, and an unstructured covariance structure.

I repeated these steps based on basal area rather than tree density. Basal area will add greater weight to larger diameter trees, likely reducing the amount of change.

\section{Results}

Using adjustments to compare different tree surveys, eastern redcedar $(+3 \%$ increase in compositional percentage) and red maple $(+2 \%)$ increased the most relative to other species in the central eastern USA, while six oak and pine species decreased ( 0.5 to $1 \%$ in composition; Table 1). In the two regions of the southeastern USA (i.e., northern Southeast and Coastal Plain), loblolly 
Table 1 Compositional change between older and newer tree surveys, adjusted for comparison (species $\geq 1.5 \%$ currently; change $=$ new percentage - old percentage; ratio $=$ new percentage/old percentage), shade tolerance values, and tree strategy group. Adjustments to equalize survey effort make the differences between values more suitable to assess

\begin{tabular}{|c|c|c|c|c|c|c|c|c|}
\hline Region & Scientific name & Common name & Old \% & New \% & Change & Ratio & Shade & Group \\
\hline \multirow[t]{17}{*}{ Central eastern } & Acer rubrum & Red maple & 13.22 & 15.11 & 1.88 & 1.14 & 3.44 & Mid-successional \\
\hline & Acer saccharum & Sugar maple & 7.72 & 8.65 & 0.93 & 1.12 & 4.76 & Late-successional \\
\hline & Pinus strobus & Eastern white pine & 5.86 & 6.76 & 0.90 & 1.15 & 3.21 & Mid-successional \\
\hline & Juniperus virginiana & Eastern redcedar & 3.28 & 6.41 & 3.14 & 1.96 & 1.28 & Early-successional \\
\hline & Quercus alba & White oak & 5.12 & 3.97 & -1.16 & 0.77 & 2.85 & Fire-tolerant oaks \\
\hline & Betula lenta & Sweet birch & 2.17 & 2.92 & 0.75 & 1.35 & 2.58 & Mid-successional \\
\hline & Pinus virginiana & Virginia pine & 3.88 & 2.78 & -1.09 & 0.72 & 1.99 & Early-successional \\
\hline & Liriodendron tulipifera & Yellow-poplar & 3.01 & 2.77 & -0.24 & 0.92 & 2.07 & Early-successional \\
\hline & Quercus prinus & Chestnut oak & 3.16 & 2.66 & -0.50 & 0.84 & 2.85 & Fire-tolerant oaks \\
\hline & Pinus echinata & Shortleaf pine & 3.19 & 2.32 & -0.87 & 0.73 & 1.86 & Early-successional \\
\hline & Quercus rubra & Northern red oak & 2.91 & 2.27 & -0.64 & 0.78 & 2.75 & Fire-tolerant oaks \\
\hline & Quercus velutina & Black oak & 3.07 & 2.15 & -0.92 & 0.70 & 2.72 & Fire-tolerant oaks \\
\hline & Tsuga canadensis & Eastern hemlock & 1.63 & 2.12 & 0.48 & 1.30 & 4.83 & Late-successional \\
\hline & Prunus serotina & Black cherry & 1.56 & 2.12 & 0.56 & 1.36 & 2.46 & Early-successional \\
\hline & Fraxinus americana & White ash & 2.28 & 1.90 & -0.39 & 0.83 & 2.46 & Early-successional \\
\hline & Acer negundo & Boxelder & 0.86 & 1.71 & 0.85 & 1.99 & 3.47 & Mid-successional \\
\hline & Carya glabra & Pignut hickory & 0.92 & 1.51 & 0.59 & 1.64 & 2.69 & Mid-successional \\
\hline \multirow[t]{10}{*}{ Northern Southeast } & Pinus taeda & Loblolly pine & 26.10 & 37.59 & 11.49 & 1.44 & 1.99 & Planted pines \\
\hline & Pinus echinata & Shortleaf pine & 21.84 & 7.96 & -13.88 & 0.36 & 1.86 & Fire-tolerant pines \\
\hline & Liquidambar styraciflua & Sweetgum & 6.17 & 6.80 & 0.63 & 1.10 & 1.59 & Early-successional \\
\hline & Juniperus virginiana & Eastern redcedar & 2.43 & 5.66 & 3.23 & 2.33 & 1.28 & Early-successional \\
\hline & Acer rubrum & Red maple & 4.03 & 5.45 & 1.42 & 1.35 & 3.44 & Mid-successional \\
\hline & Pinus virginiana & Virginia pine & 5.59 & 4.79 & -0.80 & 0.86 & 1.99 & Early-successional \\
\hline & Liriodendron tulipifera & Yellow-poplar & 1.96 & 2.89 & 0.93 & 1.47 & 2.07 & Early-successional \\
\hline & Quercus alba & White oak & 2.94 & 2.58 & -0.36 & 0.88 & 2.85 & Fire-tolerant oaks \\
\hline & Quercus nigra & Water oak & 1.33 & 1.73 & 0.40 & 1.30 & 2.25 & Early-successional \\
\hline & Carpinus caroliniana & American hornbeam & 0.86 & 1.52 & 0.66 & 1.77 & 4.58 & Late-successional \\
\hline \multirow[t]{11}{*}{ Coastal Plain } & Pinus taeda & Loblolly pine & 24.97 & 35.44 & 10.47 & 1.42 & 1.99 & Planted pines \\
\hline & Pinus elliottii & Slash pine & 12.72 & 13.16 & 0.43 & 1.03 & 1.99 & Planted pines \\
\hline & Acer rubrum & Red maple & 7.37 & 7.63 & 0.26 & 1.04 & 3.44 & Mid-successional \\
\hline & Liquidambar styraciflua & Sweetgum & 5.03 & 4.71 & -0.33 & 0.94 & 1.59 & Early-successional \\
\hline & Pinus palustris & Longleaf pine & 6.93 & 3.71 & -3.22 & 0.53 & 0.87 & Fire-tolerant pines \\
\hline & Nyssa biflora & Swamp tupelo & 4.21 & 3.02 & -1.18 & 0.72 & 2.00 & Early-successional \\
\hline & Quercus nigra & Water oak & 2.11 & 2.75 & 0.64 & 1.30 & 2.25 & Early-successional \\
\hline & Taxodium distichum & Bald cypress & 2.75 & 2.21 & -0.54 & 0.80 & 2.13 & Early-successional \\
\hline & Taxodium ascendens & Pond cypress & 2.41 & 1.77 & -0.64 & 0.73 & 2.13 & Early-successional \\
\hline & Quercus laurifolia & Laurel oak & 1.18 & 1.77 & 0.58 & 1.49 & 3.34 & Mid-successional \\
\hline & Pinus echinata & Shortleaf pine & 5.33 & 1.64 & -3.69 & 0.31 & 1.86 & Fire-tolerant pines \\
\hline
\end{tabular}

pine increased by 10 percentage points in composition, from about 25 to $35 \%$ of all trees. In the northern Southeast, shortleaf pine decreased $14 \%$ in composition, while in the Coastal Plain, shortleaf pine and longleaf pine each decreased about $3.5 \%$ in composition. Eastern redcedar also increased by 3 percentage points in the northern Southeast. Please note that table values reflect adjustments to equalize different survey methods, and 
thus, the differences rather than actual values are most suitable.

By tree strategy group, in the central eastern USA, there appeared to be fairly equitable replacement of firetolerant oaks $(-4.5 \%$ composition) by mid-successional species $(+3.4 \%)$, with a little progression to latesuccessional species $(+1.7 \%)$, and no loss of earlysuccessional species (Table 2). In the northern Southeast, planted pines increased $11 \%$ in composition and earlysuccessional species increased $4.5 \%$ in composition, while fire-tolerant pines decreased $14.5 \%$ in composition and fire-tolerant oaks decreased $3.5 \%$ in composition. Planted pines increased $10.5 \%$ in composition, while fire-tolerant pines decreased $7 \%$ in composition in the Coastal Plain. Early- and mid-successional species decreased slightly and late-successional species increased $1 \%$ in composition.

After assigning each ecological subsection to the most abundant tree strategy group, to provide an indication of transitions in strategy groups, 70 to $87 \%$ of subsections retained the most abundant group by region (Table 3 ). In the central eastern USA, $40.9 \%$ of subsections remained mid-successional, while in the two regions in the Southeast, $40.7 \%$ and $63.6 \%$ of subsections remained in planted pines. For transitions, the most common transition (19\%) was from the early-successional to mid-successional group in the central eastern USA;

Table 2 Change in tree strategy groups between older and newer tree surveys, adjusted for comparison (change = new percentage - old percentage; ratio = new percentage/old percentage)

\begin{tabular}{llllll}
\hline Region & Group & Old \% & New \% & Change & Ratio \\
\hline Central eastern & Early-successional & 25.9 & 25.9 & 0.1 & 1.0 \\
& Mid-successional & 38.0 & 41.4 & 3.4 & 1.1 \\
& Late-successional & 13.7 & 15.3 & 1.7 & 1.1 \\
& Fire-tolerant oaks & 18.8 & 14.3 & -4.5 & 0.8 \\
& Fire-tolerant pines & 3.2 & 2.3 & -0.9 & 0.7 \\
& Planted pines & 0.3 & 0.7 & 0.4 & 2.2 \\
Northern Southeast & Early-successional & 21.9 & 26.3 & 4.4 & 1.2 \\
& Mid-successional & 14.5 & 16.0 & 1.6 & 1.1 \\
& Late-successional & 3.0 & 4.0 & 1.0 & 1.3 \\
& Fire-tolerant oaks & 10.9 & 7.5 & -3.4 & 0.7 \\
& Fire-tolerant pines & 22.9 & 8.4 & -14.6 & 0.4 \\
& Planted pines & 26.7 & 37.8 & 11.0 & 1.4 \\
& Early-successional & 25.2 & 23.0 & -2.2 & 0.9 \\
& Mid-successional & 17.3 & 16.8 & -0.5 & 1.0 \\
& Late-successional & 2.9 & 3.8 & 0.9 & 1.3 \\
& Fire-tolerant oaks & 4.0 & 2.1 & -1.9 & 0.5 \\
& Fire-tolerant pines & 12.4 & 5.4 & -7.0 & 0.4 \\
& Planted pines & 38.2 & 48.9 & 10.7 & 1.3 \\
\hline \multirow{5}{*}{ Coastal Plain } & & & &
\end{tabular}

33 subsections increased in the majority shade tolerance class, and six subsections decreased in the majority shade tolerance class, while seven subsections transitioned from a majority of fire-tolerant oaks to early-successional species. In the northern Southeast, fire-tolerant pine converted to planted pine (12\%), and in the Coastal Plain, the early-successional group converted to planted pine (11\%).

Mean shade tolerance increased from 2.92 to 2.97, an increase of $2 \%$ (i.e., $102 \%$ of previous value) in the central eastern USA (Table 4). Mean shade tolerance increased from 2.19 to 2.25 , an increase of $2 \%$ (i.e., $102 \%$ of previous value) in the northern Southeast. Mean shade tolerance increased from 2.18 to 2.26, an increase of $4 \%$ (i.e., $104 \%$ of previous value) in the Coastal Plain. By ecological subsection, most of the ratios of recent to older shade tolerance values were \pm 10 \% (i.e., most ratios were 0.9 to 1.1 ). Change in shade tolerance was significant for the central East and Coastal Plain $(P<0.0001)$. The northern Southeast had borderline significance $(P=0.0493)$.

Results based on basal area instead of density were similar (see Additional file 1: Tables S1-S4). The most notable differences occurred in the central East. Midsuccessional species increased more than fire-tolerant oaks decreased, unlike results based on density, and early-successional species decreased rather than remained stable based on density (Additional file 1: Table S2). Thus, the successional groups were more dynamic. Fire-tolerant oaks transitioned to early-successional species in six subsections and transitioned to mid-successional species in three subsections, whereas based on density, fire-tolerant oaks transitioned to early-successional species in seven subsections with no other transitions (Additional file 1: Table S3). Thus, there is less of an apparent pattern of transition from fire-tolerant oaks to early-successional species to mid-successional species. Mid-successional species apparently gained greater representation in forests from diameter growth than increased densities, whereas early-successional species remained stable in number but lost larger diameter trees, and fire-tolerant oaks lost both, but more in density than diameter.

\section{Discussion}

Successional shifts to species of greater shade tolerance is a slow process, and thus far, there were a few indications that succession was proceeding, albeit not entirely consistently. Overall, there was a slight increase of 2 to $4 \%$ (i.e., increase by a factor of 1.02 to 1.04 ) in mean shade tolerance by region, which was significant in all three regions (Table 4). The size of this effect may be too small to be ecologically important at regional scales, reducing support for a strong unequivocal trend in succession. In the central eastern USA, an increase in 10 to 
Table 3 Transition among majority shade tolerance and oak and pine groups by ecological subsection $(N)$ between older and newer tree surveys, adjusted for comparison

\begin{tabular}{|c|c|c|c|c|}
\hline Region & Transition & & $N$ & $\begin{array}{l}\% \text { of } \\
\text { subsections }\end{array}$ \\
\hline \multirow[t]{10}{*}{ Central eastern } & Mid-successional & Mid-successional & 65 & 40.9 \\
\hline & Early-successional & Early-successional & 43 & 27.0 \\
\hline & Early-successional & Mid-successional & 30 & 18.9 \\
\hline & Fire-tolerant oaks & Early-successional & 7 & 4.4 \\
\hline & Mid-successional & Early-successional & 3 & 1.9 \\
\hline & Late-successional & Mid-successional & 3 & 1.9 \\
\hline & Fire-tolerant oaks & Fire-tolerant oaks & 3 & 1.9 \\
\hline & Early-successional & Late-successional & 2 & 1.3 \\
\hline & Late-successional & Late-successional & 2 & 1.3 \\
\hline & Mid-successional & Late-successional & 1 & 0.6 \\
\hline \multirow[t]{8}{*}{ Northern Southeast } & Planted pines & Planted pines & 24 & 40.7 \\
\hline & Early-successional & Early-successional & 17 & 28.8 \\
\hline & Fire-tolerant pines & Planted pines & 7 & 11.9 \\
\hline & Early-successional & Planted pines & 4 & 6.8 \\
\hline & Fire-tolerant pines & Early-successional & 3 & 5.1 \\
\hline & Mid-successional & Mid-successional & 2 & 3.4 \\
\hline & Early-successional & Mid-successional & 1 & 1.7 \\
\hline & Fire-tolerant oaks & Planted pines & 1 & 1.7 \\
\hline \multirow[t]{5}{*}{ Coastal Plain } & Planted pines & Planted pines & 35 & 63.6 \\
\hline & Early-successional & Early-successional & 10 & 18.2 \\
\hline & Early-successional & Planted pines & 6 & 10.9 \\
\hline & Mid-successional & Mid-successional & 3 & 5.5 \\
\hline & Mid-successional & Early-successional & 1 & 1.8 \\
\hline
\end{tabular}

$20 \%$ in mean shade tolerance may be ecologically meaningful at landscape scales in some subsections of the Great Lake states (i.e., Minnesota, Wisconsin, and Michigan; Fig. 2). Also in the central eastern USA, where about $83 \%$ of species were classed in the successional groups, thirty subsections with a majority of early-successional species transitioned to a majority of mid-successional species, but percent of early-successional species held constant based on tree densities.

Instead, the foremost trends were state transition from fire-tolerant oak and pine species to fire-sensitive species with a variety of shade tolerances and gains in planted pine trees, which were more consistent than

Table 4 Change in mean shade tolerance between older and newer FIA surveys, adjusted for comparison, and information from generalized linear mixed models

\begin{tabular}{llllllll}
\hline Region & Old & New & Change & Ratio & $P$ & $F$ & Den DF \\
\hline Central eastern & 2.92 & 2.97 & 0.05 & 1.02 & $<.0001$ & 16.6 & 158 \\
Northern Southeast & 2.19 & 2.25 & 0.05 & 1.02 & 0.0493 & 4.03 & 58 \\
Coastal Plain & 2.18 & 2.26 & 0.08 & 1.04 & $<.0001$ & 54.7 & 54 \\
\hline
\end{tabular}

succession during both the time frame of this study and longer time intervals, particularly in the southeastern USA where only about $45 \%$ of species were in the successional groups (Tables 1 and 2; Figs. 1 and 3). Shade-tolerant groups were affected by generally greater losses and gains in fire-tolerant oaks and pines and planted pines. Planted loblolly pine now is the most abundant species in the Southeast. Longleaf pine used to dominate forests in the Coastal Plain ( $\geq 75 \%$ of all trees), and due to frequent, low-severity surface fires that removed tree regeneration, forests were of an open structure with limited tree presence in the mid- and understories; instead, a ground layer of herbaceous vegetation was present and provided fuels to spread surface fire (Hanberry and Nowacki 2016; Hanberry et al. 2018a, b). Since fire exclusion during the early 1900s, longleaf pine has decreased (3.7\% of trees in the Coastal Plain, Table 1) to where it is less common than fire-sensitive red maple and sweetgum (Liquidambar styraciflua), while forests have become more dense without fire to control understory tree growth. Likewise, historically open forests of shortleaf pine and fire-tolerant oaks have declined in the other two 
Differentiating characteristics of two forest trends

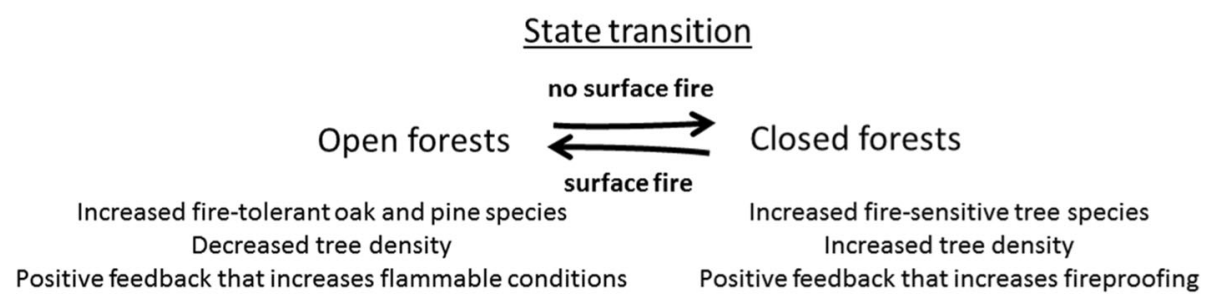

Compositional succession

stand-replacing disturbance

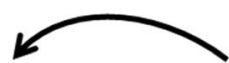

early-successional species

late-successional species

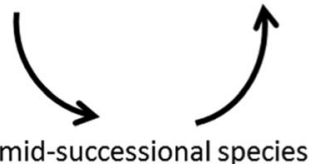

Fig. 3 State transition from open forests of fire-tolerant species to closed forests of fire-sensitive species contrasted with compositional succession to species of increasingly greater shade tolerance. This study demonstrates the continued long-term decrease in fire-tolerant oaks and pines and increase in fire-sensitive species, which do not need to be shade tolerant

regions since fire exclusion while closed forests of firesensitive species and planted pines have increased.

The concept of mesophication (Nowacki and Abrams 2008) conveys the measureable state transition from fire-tolerant oak and pine species, and their associated open forest structure, to fire-sensitive species of dense forests as surface fire is excluded and forests become more resistant to surface fires, due in part to replacement of herbaceous vegetation that spreads fire by increased number of trees (but less resistant to severe fires as fuels build up to the crown; Fig. 3). The successional component of transition to mesic species of increased shade tolerance is not necessary (Fig. 3). Indeed, it appears that earlysuccessional species more directly may be replacing fire-tolerant oaks, as a retrogression, followed by replacement of early-successional species by a variety of mid-successional species, which are relatively comparable in shade tolerance to oaks. This sequence, even though indicated by transitions in most abundant tree strategy groups (Table 3), is not clear because the two part shift results in decreased oaks and increased mid-successional species, notably red maple, which is more shade-tolerant than oaks. Nonetheless, it is important to differentiate the process of mesophication (i.e., a state transition) from succession to more mesic species (Fig. 3).

Broadening the definition of mesophytic species from shade-tolerant to fire-sensitive species may help clarify the two processes. Fire-tolerant pine and oak species often are labeled as "shade-intolerant" or "mid-shadetolerant" and given successional terms, but the major characteristic of oaks and pines is fire tolerance, permitting them to dominate under low-severity fire regimes, which filtered other species historically (Figs. 1 and 3). Disturbance change shifted the relevance of life history traits, so that traits dedicated to fire tolerance are no longer necessary. Fire exclusion enables fire-intolerant tree species to survive and recruit to sizes less susceptible to fire injury. As fire exclusion is prolonged and woody vegetation biomass accumulates, flammability decreases due to loss of fine fuels from the herbaceous layer and changing leaf litter of dominant species (while increasing the severity of future fires; Kreye et al. 2013; Hanberry et al. 2018a).

Forests in the two regions of the southeastern USA are not succeeding to later successional species primarily because pine plantations are preventing successional change. Planted trees in plantations displace any life history strategies (Fig. 1). Despite minor presence constricted to wet soils (i.e., loblolly soils) protected from fire and limited range historically, loblolly pine now is the most common species in the eastern USA due to plantations. Species increasing in number are favored by land uses such as forestry and landscaping, or tree planting for variety of reasons, such as reduced exposure to sun and wind or ornamental features (Table 1). These land uses may be the greatest influences on tree composition in current forests. 
Overstory tree removal by cutting for various land uses allows establishment of less shade-tolerant species, and the cumulative impacts of a variety of land uses are interfering with competition for light, impeding succession to late-successional species (Hanberry et al. 2014; Nowacki and Abrams, 2008). Pan et al. (2011) used FIA surveys to determine that more than $80 \%$ of the forested area in the southeastern USA was less than 60 years, with few stands greater than 80 years, and most of the forests in the central eastern USA were 40 to 80 years. Relatively frequent overstory disturbance is favoring species with low to moderate shade tolerance, which is similar to the shade tolerance of oaks and pines. Currently, red maple (shade tolerance of 3.4; Niinemets and Valladares 2006) and eastern redcedar (shade tolerance of 1.3) are two species most favored by land use and decreasing oak dominance, excluding planted pines. Red maple, because of generalist traits of prolific seeding and growth under a range of shade conditions, establishes competitively after harvest (Abrams 1998). Red maple monopolizes growing space in smaller gaps, whereas eastern redcedar colonizes non-treed growing space, particularly with assistance from plantings and wildlife (Hanberry and Hansen, 2015). Black cherry (Prunus serotina) also probably responds well to harvest, and the frequency and size of harvest may favor sweet birch (Betula lenta) and eastern white pine (Pinus strobus), which establish post-disturbance (Abrams and Nowacki 1992; Blankenship and Arthur 1999). Disturbance return intervals will need to be longer than the typical maximum lifespan of red maple and eastern redcedar (i.e., 80 to 150 years; Loehle 1988) for succession to progress. Furthermore, this disturbance-free timeline must be further extended to allow shade-tolerant species to successfully compete under an overstory and capture the overstory.

The frequency of overstory removal due to various land uses will determine whether late-successional forests ever develop at landscape scales. Progression from earlysuccessional species to mid-successional species suggests a trend that will strengthen over time, through decreasing percent of early-successional species and increasing mean shade tolerance, as the transition from fire-tolerant oaks comes to completion. However, although succession to very shade-tolerant tree species is one potential trajectory of eastern forests, continued compositional progression in shade tolerance may not occur due to too frequent overstory disturbance (Pan et al. 2011). Current forests are not old growth forests, as historical forests were, and may not have time before stand removal to progress from shadeintolerant colonizers to increasingly shade-tolerant competitors. It may take hundreds of years for compositional succession to late-successional species to become apparent in forests, unlike structural development from clearcuts to dense, small diameter forests.
Forests at landscape scales comprised of numerous earlyto mid-successional fire-sensitive species, particularly red maple and eastern redcedar, probably are unprecedented, at least during the latest interglacial period. Contemporary forest communities may be impermanent and unpredictable compared to dominance by long-lived oak and pine species. Many species have functional traits related to successful colonization and competition in the absence of fire stress, and therefore, competitive dynamics in current eastern broadleaf forests have become less restricted and more uncertain. It may be more likely that the same species favored by harvest regimes and landscaping will continue to densify and expand rather than compositional conversion to species with greater shade tolerance over time. Loblolly pine plantations probably will continue to extend into the central eastern USA. Red maple will remain extremely competitive under frequent (e.g., < 100 years) overstory tree disturbance. Landscaping and wildlife will favor trees with attractive foliage, flowers, and seeds, such as red maple (foliage), black cherry and eastern redbud (Cercis canadensis; flowers), and black cherry and eastern redcedar (seeds spread by birds, Auclair and Cottam, 1971; Holthuijzen and Sharik 1985). In areas with greater frequency of land disturbance, due to agriculture or harvest, less shade-tolerant, colonizing species will be more abundant.

Non-oak species that are declining may be affected by some combination of land use (i.e., harvest removal or preference for other species for forestry products and landscaping), insects, and disease. Introduced insects and disease will collapse the ash genus (i.e., the Asian emerald ash borer; Agrilus planipennis), similarly to loss of the American chestnut (Castanea dentata) by chestnut blight (an Asian bark fungus; Cryphonectria parasitica), whereas eastern hemlock and American beech are infected by the Asian wooly adelgid (Adelges tsugae) and beech bark disease (a European beech scale insect, Cryptococcus fagisuga, with lethal fungal infections by Neonectria spp.). Decreases of these species will provide competitive opportunities for other species. Projected extreme fluctuations in water availability, even within seasons and years, may result in any number of possible future combinations of species across forest landscapes. Lengthened dry intervals due to climate change may cause drought and stress tolerance to be a more successful strategy in future forest ecosystems, which will favor less shade-tolerant tree species that are adapted to exposure and environmental fluctuations outside of the more stable conditions of closed forest canopies.

\section{Conclusion}

I used this study to determine what succession may look like, particularly in the central eastern region of the USA where forests are about 60 years old and aging (Pan et al. 2011). Rather than clear increases in shade tolerance, 
major trends were losses in fire-tolerant oaks and pines and gains in planted pines, particularly in the southeastern USA. Succession currently is obscured by the longterm state transition or regime shift from fire-tolerant oak and pine species to fire-sensitive species, which are not late-successional, because of fire exclusion and current land use that favors planted species and species competitive after overstory tree removal. Unlike firemaintained open forest ecosystems dominated by a few species of oak and pine, current forests contain a large number of species of moderate abundance that are of low to moderate shade tolerance and favored by forestry products and land use practices. If return interval of overstory removal is less than the lifetime of overstory tree species, there is no time for forests to develop in composition to species with great shade tolerance, or to more open, large diameter old-growth structure. Just as land use by fire may be the greatest influence on tree distributions in historical forests, land use appeared to the greatest influence on current forests, obstructing competitive dynamics for light.

\section{Additional file}

Additional file 1: Supplementary tables. This file contains supplementary Tables S1-S4. (DOCX $21 \mathrm{~kb}$ )

\section{Acknowledgements}

I thank L.S. Baggett and J. Ott for statistical assistance, M. Hansen for FIA survey adjustments, and G. Nowacki and M. Abrams for reviews.

\section{Authors' contributions}

$\mathrm{BH}$ wrote all the sections and approved the final manuscript.

\section{Funding}

There was no funding for this project.

\section{Availability of data and materials}

Tree information is available at FIA DataMart, http://www.fia.fs.fed.us/toolsdata.

Ethics approval and consent to participate

Not applicable

\section{Consent for publication}

Not applicable

\section{Competing interests}

The author declare that he/she has no competing interests.

Received: 22 April 2019 Accepted: 4 July 2019

Published online: 13 August 2019

\section{References}

Abrams MD (1998) The red maple paradox: what explains the widespread expansion of red maple in eastern forests? BioScience 48:355-364

Abrams MD, Nowacki GJ (1992) Historical variation in fire, oak recruitment, and post-logging accelerated succession in central Pennsylvania. Bull Torrey Bot Club 119:19-28 http://www.jstor.org/stable/2996916

Arthur MA, Alexander HD, Dey DC, Schweitzer CJ, Loftis DL (2012) Refining the oak-fire hypothesis for management of oak-dominated forests of the eastern United States, J For 110:257-266. https://doi.org/10.5849/ jof.11-080
Auclair AN, Cottam G (1971) Dynamics of black cherry (Prunus serotina Erhr.) in southern Wisconsin oak forests. Ecol Monogr 41:153-177

Bechtold WA, Patterson PL (2005) The enhanced forest inventory and analysis program - national sampling design and estimation procedures. Gen. Tech. Rep. SRS-80. USDA Forest Service, Southern Research Station, Asheville, NC

Blankenship BA, Arthur MA (1999) Prescribed fire affects eastern white pine recruitment and survival on eastern Kentucky ridgetops. South J Appl For 23 $144-150$

Bowman DMJS, O'Brien JA, Goldammer JG (2103) Pyrogeography and the global quest for sustainable fire management. Annual Review of Environment and Resources 38:57-80

Brown ML, Canham CD, Murphy L, Donovan TM (2018) Timber harvest as the predominant disturbance regime in northeastern US forests: effects of harvest intensification. Ecosphere 9:e02062

Conner RC, Hartsell AJ (2002) Forest area and conditions. In: In DN Wear and JG Greis (eds) Southern forest resource assessment. GTR SRS-53. USDA Forest Service, Southern Research Station, Asheville, NC, pp 357-402

Ecomap (2007) National hierarchical framework of ecological units. USDA Forest Service, Washington, DC, USA

Egerton FN (2015) History of ecological sciences, Part 54: Succession, community, and continuum. Bull Ecol Soc Am 96:426-474. https://doi. org/10.1890/0012-9623-96.3.426

Frost CC (1993) Four centuries of changing landscape patterns in the longleaf pine ecosystem. In: SM Hermann (ed), Proceedings of the Tall Timbers fire ecology conference. Tall Timbers Research Station, vol 18, Tallahassee, FL, pp $17-43$

Grime JP (1977) Evidence for the existence of three primary strategies in plants and its relevance to ecological and evolutionary theory. Am Nat 111:1169-1194 http://www.jstor.org/stable/2460262

Grimm EC, Jacobson GL (1992) Fossil-pollen evidence for abrupt climate changes during the past 18000 years in eastern North America. Clim Dyn 6:179-184

Hanberry BB (2019) Trajectory from beech and oak forests to eastern broadleaf forests in Indiana, USA. Ecol Process 8:3

Hanberry BB, Bragg DC, Hutchinson TF (2018a) A reconceptualization of open oak and pine ecosystems of eastern North America using a forest structure spectrum. Ecosphere 9(10):e02431

Hanberry BB, Brzuszek RF, Foster HT II, Schauwecker TJ (2019) Recalling open old growth forests in the Southeastern Mixed Forest province of the United States. Écoscience. https://doi.org/10.1080/11956860.2018.1499282

Hanberry BB, Coursey K, Kush JS (2018b) Structure and composition of historical longleaf pine ecosystems in Mississippi, USA. Human Ecology 46:241-248 http://link.springer.com/10.1007/s10745-018-9982-1

Hanberry BB, Hansen MH (2015) Advancement of tree species across ecotonal borders into non-forested ecosystems. Acta Oecol 68:24-36. https://doi. org/10.1016/j.actao.2015.07.002

Hanberry BB, Kabrick JM, He HS (2014) Changing tree composition by life history strategy in a grassland-forest landscape. Ecosphere 6:277. https://doi.org/10.1 890/ES13-00345.

Hanberry BB, Nowacki GJ (2016) Oaks were the historical foundation genus of the east-central United States. Quat Sci Rev 145:94-103

Hart J, Kleinman J (2018) What are intermediate-severity forest disturbances and why are they important? Forests 9:579

Holthuijzen AM, Sharik TL (1985) The avian seed dispersal system of eastern red cedar (Juniperus virginiana). Can J Bot 63:1508-1515

Kreye JK, Varner JM, Hiers JK, Mola J (2013) Toward a mechanism for eastern North American forest mesophication: differential litter drying across 17 species. Ecol Appl 23:1976-1986

Loehle C (1988) Tree life history strategies: the role of defenses. Can J For Res 18:209-222. https://doi.org/10.1139/x88-032

Niinemets Ü, Valladares F (2006) Tolerance to shade, drought, and waterlogging of temperate northern hemisphere trees and shrubs. Ecol Monogr 76:521-547

Nowacki GJ, Abrams MD (2008) The demise of fire and "mesophication" of forests in the eastern United States. BioScience 58:123-138

Pan Y, Chen JM, Birdsey R, McCullough K, He L, Deng F (2011) Age structure and disturbance legacy of North American forests. Biogeosciences 8:715-732 https://www.biogeosciences.net/8/715/2011/

Prentice IC, Bartlein PJ, Webb T (1991) Vegetation and climate change in eastern North America since the last glacial maximum. Ecology 72:2038-2056 http:// www.jstor.org/stable/1941558 
Seymour RS, White AS, deMaynadier PG (2002) Natural disturbance regimes in northeastern North America—evaluating silvicultural systems using natural scales and frequencies. For Ecol Manag 155:357-367 http://www. sciencedirect.com/science/article/pii/S0378112701005722

Williams JW, Shuman BN, Webb T, Bartlein PJ, Leduc PL (2004) Late-quaternary vegetation dynamics in North America: scaling from taxa to biomes. Ecol Monogr 74:309-334. https://doi.org/10.1890/02-4045

\section{Publisher's Note}

Springer Nature remains neutral with regard to jurisdictional claims in published maps and institutional affiliations.

\section{Submit your manuscript to a SpringerOpen ${ }^{\odot}$} journal and benefit from:

- Convenient online submission

- Rigorous peer review

- Open access: articles freely available online

High visibility within the field

- Retaining the copyright to your article

Submit your next manuscript at $\boldsymbol{\wedge}$ springeropen.com 